\title{
Aluminum- and iron-engineered biochar from sugarcane filter cake as phosphorus adsorbents and fertilizers
}

\author{
Natcha Sornhiran ${ }^{\mathrm{a}}$, Jirapat Tuntrachanida ${ }^{\mathrm{a}}$, Prapapun Malachey ${ }^{\mathrm{a}}$, Patchara Thongtuk ${ }^{\mathrm{a}}$, \\ Worachart Wisawapipat $^{\mathrm{a}, \mathrm{b}, *}$, Surachet Aramrak ${ }^{\mathrm{a}}$, Nattaporn Prakongkep ${ }^{\mathrm{c}}$ \\ a Department of Soil Science, Faculty of Agriculture, Kasetsart University, Bangkok 10900 Thailand \\ b Research Network of NANOTEC - KU on NanoCatalysts and NanoMaterials for Sustainable Energy and \\ Environment, Kasetsart University, Bangkok 10900 Thailand \\ c Office of Science for Land Development, Land Development Department, Bangkok 10900 Thailand
}

${ }^{*}$ Corresponding author, e-mail: worachart.w@ku.th

Received 30 Sep 2020

Accepted 17 Feb 2021

\begin{abstract}
Reclamation of phosphorus (P) from wastewater using metal-engineered biochar and its reuses as phosphate fertilizers could be an eco-friendly and effective technology for the sustainability of environmental and agricultural systems. Herein, we studied the P removal capacity of filter cake-engineered biochar loaded with $\mathrm{Al}$ and Fe and examined their available P release capability into the sand sample. The Al-biochar $(63.7 \mathrm{mg} / \mathrm{g}$ ) had a higher $\mathrm{P}$ retention capacity than the Fe-biochar $(33.2 \mathrm{mg} / \mathrm{g})$. Over 45 days of the incubation, Al- and Fe-biochar incorporation steadily or increasingly released adequate concentrations of available $\mathrm{P}$ to the sand sample. Furthermore, a considerable P fraction (99.4-99.8\% of the total P) remained in all metal-biochar samples, suggesting that the metal biochar could be a long-term source of the available P pool. This study highlighted the potential use of Al- and Fe-biochar for providing available $\mathrm{P}$ availability in sandy soils.
\end{abstract}

KEYWORDS: metal-engineered biochar, P sorption, sandy soil

\section{INTRODUCTION}

Biochar is a carbon-rich material with high stability produced by the carbonization of biomass under limited oxygen $[1,2]$. This material has various benefits such as promoting the water and nutrient retention capacity in soils and improving plant productivity $[1,3]$. Biochar is also documented as a low-cost and eco-friendly technology for reusing agricultural wastes to recover nutrients such as nitrate and phosphate from wastewaters that otherwise typically cause eutrophication in aquatic ecosystems $[4,5]$. Engineering biochar with metals has been an effective method, among several approaches, to elevate biochar chemical reactivity for the removal of such pollutants from industrial wastewater [6-9]. The metal-engineered biochar after wastewater $\mathrm{P}$ removal (P-laden biochar) is abundant in phosphate and has been proven for reuse and P-recycled fertilizer $[7,10]$.

To date, different metals such as $\mathrm{Al}$ and $\mathrm{Fe}$ have been used to produce engineered biochar $[7,11,12]$. Precipitated metal (oxyhydr)oxides in the biochar framework could act as the main adsorbents for P. Al-biochar and Fe-biochar containing respective metal oxides like gibbsite $(\mathrm{AlOOH})$ and magnetite $\left(\mathrm{Fe}_{2} \mathrm{O}_{3}\right)$ have also been documented as excellent $P$ adsorbents [11-13], but the information on their effects on soil P availability is lacking.

Soil phosphorus (P) availability is quite limited in many soil types such as sandy soils $[14,15]$. Conversely, P limitation in sandy soil is inherent from its properties, in which commonly there are low amounts of the clay-sized fraction with high chemical reactive sites for nutrient retention, which can promote nutrient losses through leaching by drainage [16]. Deficient available water holding capacity is also a severe constraint for sandy soils. Therefore, P-laden biochar could be a promising material that can resolve both $\mathrm{P}$ and water retention issues for this soil type $[17,18]$.

The filter cake is a by-product of the sugarcane industry with a high potential for engineered biochar production. Sugar production is an essential agricultural world product and about 180 million tons of sugar are produced globally each year with 
Thailand capable of supplying abundant sugar up to 10 million tons [19]. Many by-products including sugarcane leaves and sugarcane bagasse (2.4-2.5 ton), molasse (0.4-0.5 ton), and filter cake (0.5-0.6 ton) are created during 1 ton of sugar and sugaralcohol production, many of which can be recycled for biofuel and electricity production [20]. Some studies suggested that the filter cake was suitable as a soil amendment since it has high nutrient contents [21]. However, its stench and some diseases associated with this material are unfavorable properties for use. Wastewaters from sugar and ethanol production typically contain a high phosphate content that must be reclaimed to mitigate the environmental problem such as eutrophication and to allow its reuse as fertilizers [22]. Therefore, filter cake-engineered biochar production could be an effective technology to reuse this agricultural byproduct as an adsorbent for the removal of phosphate from wastewater and to provide available $\mathrm{P}$ in soils.

This research aims to investigate the $\mathrm{P}$ retention capacity of Al- and Fe-biochar prepared from filter cake and to examine $\mathrm{P}$ released from $\mathrm{Al}-$ and Febiochar applied in acid-washed sand. The obtained data will provide useful information on potential uses of Al- and Fe-biochar in soils with low P contents.

\section{MATERIALS AND METHODS}

\section{Preparation of metal-engineered biochar}

Filter cake material was obtained from the Eastern Sugar and Cane Company located in eastern Thailand. For the preparation of filter cake-engineered biochar, about $10 \mathrm{~g}$ of air-dried filter cake were separately impregnated with $60 \mathrm{ml}$ of $\mathrm{AlCl}_{3}$ and $\mathrm{FeCl}_{3}$ solutions $(67 \% \mathrm{w} / \mathrm{v})$ for up to $72 \mathrm{~h}$, depending on the material saturation time for each metal. The saturated material was oven-dried at $80^{\circ} \mathrm{C}$ for $24 \mathrm{~h}$. The materials were tightly packed into an alumina ceramic crucible. The closed vessel was transferred into a preheated muffle furnace $\left(600^{\circ} \mathrm{C}\right)$ and carbonized under the ambient atmosphere for $1 \mathrm{~h}$ [23]. The container was carefully translocated and unheated in a desiccator. Each metal-engineered biochar was washed several times with deionized (DI) water to remove impurities and dried at $80^{\circ} \mathrm{C}$ for $24 \mathrm{~h}$. The samples were crushed using an agate mortar, passed through $0.5-2.0 \mathrm{~mm}$ sieves, and preserved in airtight containers for further experiments. The Al- and Fe-engineered biochar samples were designated as $\mathrm{FB}_{\mathrm{Al}}$ and $\mathrm{FB}_{\mathrm{Fe}}$, respectively.

\section{Phosphorus sorption}

The P sorption capacity of biochar and filter cakeengineered biochar was investigated to determine the effects of each metal ( $\mathrm{Al}$ and $\mathrm{Fe}$ ) on $\mathrm{P}$ sorption capacity and its potential reuse as $\mathrm{P}$ fertilizer. About $0.05 \mathrm{~g}$ of each metal-engineered biochar $\left(\mathrm{FB}_{\mathrm{Al}}\right.$ and $\mathrm{FB}_{\mathrm{Fe}}$ ) were mixed with $25 \mathrm{ml}$ of separate $\mathrm{P}$ solutions (50-1000 mg P/l) in centrifuge tubes. The $P$ sorption experiment was performed in triplicates. All tubes were shaken in an orbital shaker at room temperature $\left(25 \pm 2^{\circ} \mathrm{C}\right)$ for $48 \mathrm{~h}$. The remaining $\mathrm{P}$ concentration in the equilibrium solution was determined using the molybdenum blue method after centrifugation at $2205 \mathrm{~g}$ for $15 \mathrm{~min}$. The Langmuir maximum $P$ sorption coefficient $\left(Q_{m}\right)$ for each engineered biochar was obtained by fitting the sorption data using the Langmuir equation as follows:

$$
q_{e}=\frac{Q_{m} K_{L} C_{e}}{1+K_{L} C_{e}}
$$

where $q_{e}(\mathrm{mg} / \mathrm{g})$ is the amount of $\mathrm{P}$ adsorbed to the solid, $C_{e}(\mathrm{mg} / \mathrm{l})$ is the equilibrium solution concentration of dissolved $\mathrm{P}$, and $K_{L}$ is the Langmuir binding energy constant. The $\mathrm{P}$ sorption data were also modelled using the Freundlich equation as follows:

$$
q_{e}=K_{f}\left(C_{e}\right)^{n}
$$

where the coefficient $K_{f}$ and $n$ denote Freundlich affinity and linearity constants energy, respectively.

\section{Preparation of phosphorus-laden biochar}

After obtaining $\mathrm{P}$ sorption data, the metalengineered biochar with high P content designated as P-laden biochar was produced for incubation experiments. Briefly, each metal-engineered biochar was weighed in separate centrifuged tubes and mixed with the $\mathrm{P}$ concentration at $10 \%$ of each $Q_{m}$ value using a solid:solution ratio of 1:20. The expected concentrations contain reliable $\mathrm{P}$ concentrations for the P-laden biochar after $\mathrm{P}$ retrieval from the wastewater [6]. The vessels were agitated on a mechanical shaker at room temperature for $48 \mathrm{~h}$. The aliquots were obtained using centrifugation at $2205 \mathrm{~g}$ for $15 \mathrm{~min}$ and then dried in the oven at $80^{\circ} \mathrm{C}$. All engineered biochar after $\mathrm{P}$ addition was termed as $\mathrm{FB}_{\mathrm{Al}-\mathrm{P}}$ and $\mathrm{FB}_{\mathrm{Fe}-\mathrm{P}}$. The value of phosphorus-laden biochar $\mathrm{pH}$ was measured in water at a solid to solution ratio of $1: 2$ using a $\mathrm{pH}$ meter. The total $\mathrm{P}$ concentration was obtained using Aqua regia digestion [24], followed by $\mathrm{P}$ analysis of the extraction using the colorimetric method [25]. The produced $\mathrm{FB}_{\mathrm{Al}-\mathrm{P}}$ and $\mathrm{FB}_{\mathrm{Fe}-\mathrm{P}}$ had 
Table 1 Values of $\mathrm{pH}$ and total $\mathrm{P}$ concentration $(\mathrm{mg} / \mathrm{g}$ ) in acid-washed sand and P-laden biochar prepared from filter cake loaded with $\mathrm{Al}\left(\mathrm{FB}_{\mathrm{Al}-\mathrm{P}}\right)$ and $\mathrm{Fe}\left(\mathrm{FB}_{\mathrm{Fe}-\mathrm{P}}\right)$.

\begin{tabular}{lccc}
\hline Parameter & Acid-washed sand & $\mathrm{FB}_{\mathrm{Al}-\mathrm{P}}$ & $\mathrm{FB}_{\mathrm{Fe}-\mathrm{P}}$ \\
\hline $\mathrm{pH}$ & 4.7 & 4.9 & 5.8 \\
Total P & ND* & 6.0 & 3.4 \\
\hline
\end{tabular}

*ND, not detected.

total P content of approximately 6.0 and $3.4 \mathrm{mg} / \mathrm{g}$, respectively (Table 1 ).

\section{Preparation and characterization of acid-washed sand}

Acid-washed sand was used as a representative of sandy soil without nutrients and impurities. Briefly, a bulk sample of the river sand was washed with tap water to eliminate light fractions of organic matter and suspended clays. The washed sand material was immersed in $10 \% \mathrm{HCl}$ for $24 \mathrm{~h}$ to extract remnant elements attached to the particles. The material was washed at least 3 times with tap water to remove the excess $\mathrm{H}^{+}$and $\mathrm{Cl}^{-}$ions caused by the acidwashed procedure. A few drops of silver nitrate solution were used to check for the presence of $\mathrm{Cl}^{-}$ ions. The material was washed with DI water after the complete removal of $\mathrm{Cl}^{-}$ions and then ovendried for the incubation experiment. Sand $\mathrm{pH}$ was measured in water at a solid to solution ratio of $1: 1$ using a $\mathrm{pH}$ meter [26]. The total $\mathrm{P}$ concentration was also analyzed using the above method. The field capacity was obtained by using ceramic plate extraction at 0.33 bar [27]. The $\mathrm{pH}$ of acid-washed sand was 4.7 with no total $\mathrm{P}$ content detected. The field capacity of the acid-washed sand sample was $3.0 \%(\mathrm{w} / \mathrm{w})$.

\section{Incubation experiment}

The incubation technique was used to examine the availability of $\mathrm{P}$ released from the P-laden biochar for possible use as a $\mathrm{P}$ recycling fertilizer in sandy soils that commonly have low $\mathrm{P}$ availability. For the incubation experiment, about $5 \mathrm{~g}$ of acid-washed sand were weighed in separate centrifuge tubes. The acid-washed sand was incubated with $\mathrm{FB}_{\mathrm{Al}-\mathrm{P}}$ and $\mathrm{FB}_{\mathrm{Fe}-\mathrm{P}}$. The investigation identified that the $\mathrm{FB}_{\mathrm{Al}-\mathrm{P}}$ and $\mathrm{FB}_{\mathrm{Fe}-\mathrm{P}}$ in the sand material were due to the fact that most sandy soils commonly have low $\mathrm{P}$ availability and low water and nutrient retention capability. The use of materials with strong $\mathrm{P}$ sorption capacities like $\mathrm{FB}_{\mathrm{Al}-\mathrm{P}}$ and $\mathrm{FB}_{\mathrm{Fe}-\mathrm{P}}$ was expected to release $\mathrm{P}$ slowly and thus reduce the $\mathrm{P}$ loss by leaching. Each type of engineered biochar was placed in nylon bags with a $100 \mu \mathrm{m}$ mesh diameter. An application rate of $1 \%(\mathrm{w} / \mathrm{w})$ was used in this study.

The moisture contents of the sand sample were maintained at $90 \%$ of its field capacity for 45 days. The tubes were placed in a controlled osmotic pressure container, which was filled with $\mathrm{NaCl}$ solution calculated by Jacobus van't Hoff equation [28, 29]. After the desired periods of 7,30 , and 45 days, the samples were taken for determination of the water-extractable $\mathrm{P}$ [30] and Olsen-extractable P contents [31]. Water extraction provides information on the most readily available $\mathrm{P}$ pools for plants, whereas the Olsen extraction describes the plant available P pool through the ligand exchange mechanism. The available $\mathrm{P}$ fraction calculated from the summation of the water-extractable and Olsen-extractable $\mathrm{P}$ was calculated and reported as a relative content of the total $\mathrm{P}$ concentration in each sample. The difference in the available $\mathrm{P}$ fraction with the total $\mathrm{P}$ content denotes the long-term $\mathrm{P}$ fraction that is potentially available to plants.

\section{RESULTS AND DISCUSSION}

\section{Phosphorus sorption}

The maximum $\mathrm{P}$ adsorption capacities of all engineered biochar were higher than those of the filter cake biochar (FB). The $\mathrm{P}$ sorption data was well described by both the Langmuir and Freundlich models with the $R^{2}$ values in the ranges of $0.76-$ $0.99($ mean $=0.91)$ and 0.94-0.97 $($ mean $=0.96)$, respectively (Table 2). The $\mathrm{FB}_{\mathrm{Al}}$ sample had a higher Langmuir maximum sorption capacity $(63.7 \mathrm{mg} / \mathrm{g})$ than the $\mathrm{FB}_{\mathrm{Fe}}$ sample (33.2 mg/g, Fig. 1). Comparing these data with existing metal-engineered biochar prepared from different feedstocks, the $\mathrm{FB}_{\mathrm{Fe}}$ sample had higher $\mathrm{P}$ sorption capacity than Febiochar prepared from orange peel pyrolysis at 250 to $700^{\circ} \mathrm{C}\left(Q_{m}=0.22-1.24 \mathrm{mg} / \mathrm{g}\right)$ [13]. The $\mathrm{FB}_{\mathrm{Al}}$ sample had a lower $\mathrm{P}$ retention capacity than the Al-biochar prepared from Cottonwood pyrolyzed $600{ }^{\circ} \mathrm{C}\left(Q_{m}=135 \mathrm{mg} / \mathrm{g}\right)$ [11]. The considerable variation in the $P$ retention capacity was mainly due to differences in the metal impurities in each feedstock, which can affect the formations of different types and quantities of metal (oxyhydr)oxides in the biochar structure that will act as the primary adsorbent for $\mathrm{P}$ in the aqueous solution. The Langmuir $K_{L}$ coefficient relating to $\mathrm{P}$ binding energy varied considerably from 0.003 to $0.33 \mathrm{l} / \mathrm{mg}$. The lower $K_{L}$ value was found in the $\mathrm{FB}_{\mathrm{Al}}$ sample, whereas the higher value was observed in the $\mathrm{FB}_{\mathrm{Fe}}$ samples. 
Table 2 Coefficients and correlation coefficients of Langmuir and Freundlich models for P adsorption onto filter cakeengineered biochar loaded with $\mathrm{Al}\left(\mathrm{FB}_{\mathrm{Al}}\right)$ and $\mathrm{Fe}\left(\mathrm{FB}_{\mathrm{Fe}}\right)$.

\begin{tabular}{|c|c|c|c|c|c|c|}
\hline \multirow{2}{*}{ Sample } & \multicolumn{3}{|c|}{ Langmuir } & \multicolumn{3}{|c|}{ Freundlich } \\
\hline & $\begin{array}{c}Q_{m} \\
(\mathrm{mg} / \mathrm{g})\end{array}$ & $\begin{array}{c}K_{L} \\
(1 / \mathrm{mg})\end{array}$ & $R^{2}$ & $\begin{array}{c}K_{f} \\
\left(\mathrm{mg}^{(1-\mathrm{n})} \mathrm{l}^{\mathrm{n}} / \mathrm{g}\right)\end{array}$ & $n$ & $R^{2}$ \\
\hline $\begin{array}{l}\mathrm{FB}_{\mathrm{Al}} \\
\mathrm{FB}_{\mathrm{Fe}}\end{array}$ & $\begin{array}{l}63.7 \\
33.2\end{array}$ & $\begin{array}{l}0.003 \\
0.33\end{array}$ & $\begin{array}{l}0.99 \\
0.76\end{array}$ & $\begin{array}{l}23.1 \\
0.34\end{array}$ & $\begin{array}{l}0.17 \\
0.65\end{array}$ & $\begin{array}{l}0.94 \\
0.97\end{array}$ \\
\hline
\end{tabular}

$Q_{m}=$ Langmuir sorption maximum capacity; $K_{L}=$ Langmuir binding constant; $K_{f}=$ Freundlich affinity constants; and $n=$ Freundlich linearity constant.

○ Data Langmuir

(a)

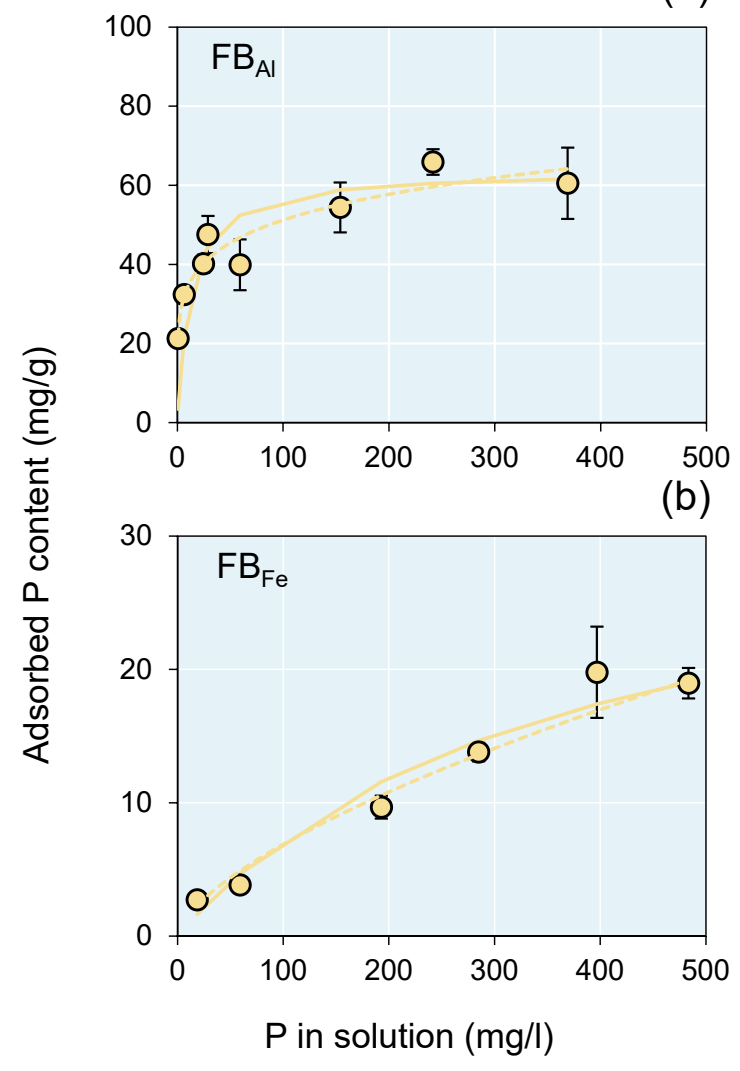

Fig. 1 Phosphorus adsorption isotherms of filter cakeengineered biochar: (a) $\mathrm{FB}_{\mathrm{Al}}$ and (b) $\mathrm{FB}_{\mathrm{Fe}}$. Symbols show experimental data, and error bars are standard errors of triplicate measurements.

These results suggested the low and high $\mathrm{P}$ binding energy for the $\mathrm{FB}_{\mathrm{Al}}$ and $\mathrm{FB}_{\mathrm{Fe}}$ samples, respectively. The difference between $K_{L}$ constant for $\mathrm{FB}_{\mathrm{Al}}$ and $\mathrm{FB}_{\mathrm{Fe}}$ samples might be attributable to the variation in crystal sizes of metal oxides formed in the engineered biochar that controlled magnitudes of specific surface area and chemical surface reactivity of the adsorbents. However, further investigation should be carried out to prove this explanation. The $K_{L}$ coefficients in this study were lower than those of Al- and Fe-biochar in previous studies reported as 0.012 and $0.046-10.51 / \mathrm{mg}$, respectively [11-13]. These data reflect that the current metal-biochar samples could be more easily released $\mathrm{P}$ and provide higher available $\mathrm{P}$ contents than other reported metal-engineered biochar samples.

The Freundlich $K_{f}$ coefficient associated with the quantity of $\mathrm{P}$ sorption sites ranged from $0.34 \mathrm{mg} / \mathrm{g}$ for the $\mathrm{FB}_{\mathrm{Fe}}$ sample to $23.1 \mathrm{mg} / \mathrm{g}$ for the $\mathrm{FB}_{\mathrm{Al}}$ sample which was lower than that of Albiochar and Fe-biochar of other studies (2971, 10.1, and 1069) [11-13]. The Freundlich $n$ constant indicating the variation of adsorption sites of sorbents differed from 0.17 for the $\mathrm{FB}_{\mathrm{Al}}$ sample to 0.65 for the $\mathrm{FB}_{\mathrm{Fe}}$ sample, while other studies found the Freundlich $n$ constant of Al-biochar at 0.40 and Fe-biochar around 0.29-0.87 [11-13]. The low value indicated the adsorption site heterogeneity, and the high value indicated the adsorption site homogeneity [32].

\section{Effect of phosphorus-laden biochar on phosphorus availability}

The results of testing for water-extractable and Olsen-extractable $\mathrm{P}$ in the acid-washed sand after 45 days of incubation with Al- and Fe-biochar are provided in Fig. 2. Different metal-engineered biochar samples released varied water-extractable and Olsen-extractable P contents into the sand sample. The acid-washed sand containing Al-biochar had water-extractable P of $0.1-0.5 \mathrm{mg} / \mathrm{kg}$ whereas the acid-washed sand contained Fe-biochar with water-extractable of $0.7-1.6 \mathrm{mg} / \mathrm{kg}$ (Fig. 3).

The Olsen-extractable $\mathrm{P}$ for the acid-washed sand in the Al-biochar series was somewhat stable over the 45 days of the incubation (11.4 to $12.4 \mathrm{mg} / \mathrm{kg}$ ) while that in the Fe-biochar series was considerably increased during the incubation period (9.1 to $19.2 \mathrm{mg} / \mathrm{kg}$ ). The constant release of available P from Al-biochar may be due to the more stable 
Table 3 Water-extractable and Olsen-extractable P contents in acid-washed sand over 45 days of incubation with Al$\left(\mathrm{FB}_{\mathrm{Al}-\mathrm{P}}\right)$ and Fe-biochar $\left(\mathrm{FB}_{\mathrm{Fe}-\mathrm{P}}\right)$.

\begin{tabular}{|c|c|c|c|c|c|c|}
\hline \multicolumn{7}{|c|}{ Available P (mg/kg) } \\
\hline \multirow[t]{2}{*}{ Extraction } & \multicolumn{3}{|c|}{$\mathrm{FB}_{\mathrm{Al}-\mathrm{P}}$ treatment } & \multicolumn{3}{|c|}{$\mathrm{FB}_{\mathrm{Fe}-\mathrm{P}}$ treatment } \\
\hline & Day 7 & Day 30 & Day 45 & Day 7 & Day 30 & Day 45 \\
\hline Water & $0.5 \pm 0.01$ & $0.1 \pm 0.08$ & $0.2 \pm 0.07$ & $1.1 \pm 0.03$ & $0.7 \pm 0.02$ & $1.6 \pm 0.41$ \\
\hline Olsen & $11.4 \pm 2.74$ & $11.7 \pm 0.95$ & $12.4 \pm 1.63$ & $9.1 \pm 1.57$ & $14.0 \pm 2.61$ & $19.2 \pm 1.70$ \\
\hline
\end{tabular}

\section{Water extraction $\quad \square$ Olsen extraction}

(a)

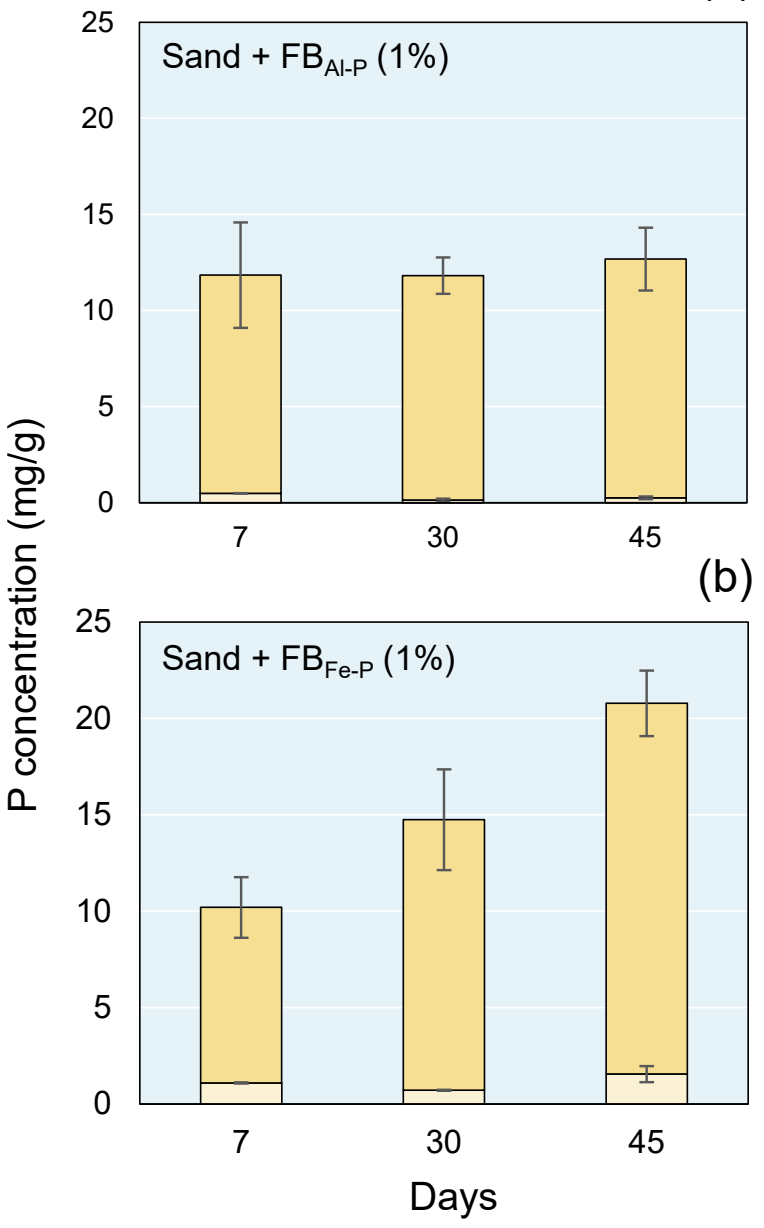

Fig. 2 Water- and Olsen-extractable $\mathrm{P}$ concentration of acid-washed sand treated with (a) $\mathrm{FB}_{\mathrm{Al}-\mathrm{P}}$ and (b) $\mathrm{FB}_{\mathrm{Fe}-\mathrm{P}}$. Bar graphs show experimental data, and error bars are standard errors of triplicates.

phase of Al oxides in the engineered biochar sample, whereas the increasing $\mathrm{P}$ concentration released with time from Fe-biochar is consistent with the heterogeneity of the adsorption sites of the biochar that may control different $P$ release behaviors from the Fe-biochar sample. Interestingly, the high Olsen- extractable $\mathrm{P}$ values in the $\mathrm{Al}$ - and Fe-biochar series suggest the possible uses of the Al- and Febiochar samples, which are typically thought to be unsuitable for plant use, for improving the available $\mathrm{P}$ content in sandy soils with a low native P. The release of $\mathrm{P}$ from the $\mathrm{Al}$ - and $\mathrm{Fe}$-biochars could have been due to the replacement of orthophosphate ions $\left(\mathrm{H}_{2} \mathrm{PO}_{4}^{-}\right.$or $\left.\mathrm{HPO}_{4}^{2-}\right)$ with $\mathrm{HCO}_{3}^{-}$ions by the ligand exchange process. This exchange process resembles the release of $\mathrm{HCO}_{3}^{-}$ions from plant roots to acquire anions [33]. The data were consistent with recent research demonstrating that the uses of Fe(II)- and $\mathrm{Fe}(\mathrm{III})$-biochar could improve $\mathrm{P}$ availability in paddy through the reductive dissolution of Fe oxides in biochar upon flooding [34].

In general, Olsen-extractable $\mathrm{P}$ is considered to be available for plant uptake [35]. Considering extractable $\mathrm{P}$ from all metal-engineered biochar samples $\left(\mathrm{FB}_{\mathrm{Al}-\mathrm{P}}\right.$ and $\left.\mathrm{FB}_{\mathrm{Fe}-\mathrm{P}}\right)$ treated in the acidwashed sand with the low total and available $\mathrm{P}$ content, the results demonstrated that the concentration of the Olsen-extractable P in all incubation series was typically greater than the critical value for corn production as assessed using Olsen extraction of $5.0 \mathrm{mg} / \mathrm{kg}$ [36]. The data suggested that applications of $\mathrm{FB}_{\mathrm{Al}-\mathrm{P}}$ and $\mathrm{FB}_{\mathrm{Fe}-\mathrm{P}}$ at the rate of $1 \%(\mathrm{w} / \mathrm{w})$, corresponding to 19.50 ton/ha in soils, could provide sufficient amounts of available $P$ for the entire period of productions for certain economic crops such as corn.

Moreover, the available P pools (calculated from both water- and Olsen-extractable P) were very low compared to the total $\mathrm{P}$ in each metal-P biochar. The relative fraction of available $\mathrm{P}$ was just $0.20-0.21 \%$ and $0.30-0.61 \%$ of the total $\mathrm{P}$ for the $\mathrm{FB}_{\mathrm{Al}-\mathrm{P}}$ and $\mathrm{FB}_{\mathrm{Fe}-\mathrm{P}}$ biochar samples, respectively, which were continuously released to the sand during the 45day incubation (Fig. 3). Other studies of P release from metal-engineered biochar by similar production were focused mainly on single extraction from Mg-biochar, in which 0.01 to $14 \%$ of their total P can be extracted by citric acid, $\mathrm{KCl}$, and Mehlich-3 [37-39]. These data reflect that substantial fractions of reserved $\mathrm{P}$ pools could have remained in the 


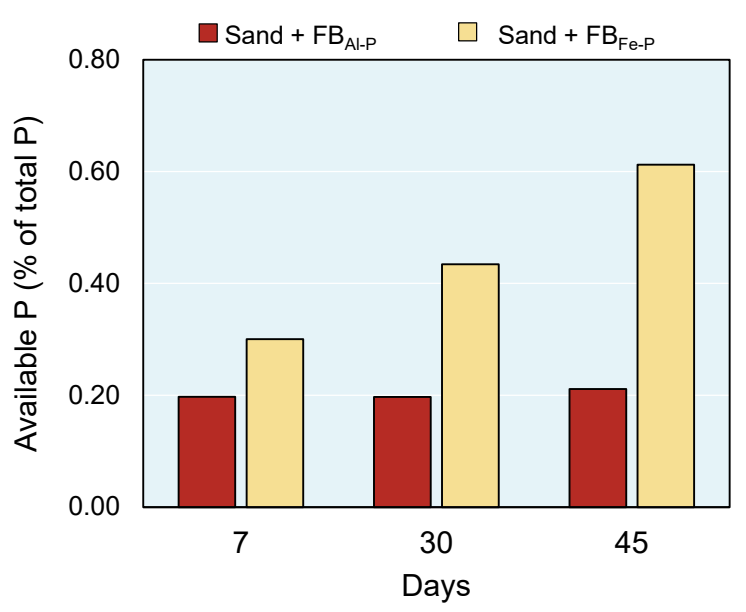

Fig. 3 Relative percentage (\% of total $\mathrm{P}$ ) of available $\mathrm{P}$ content (water and Olsen extractable) for P-laden biochar prepared from filter cake loaded with $\mathrm{Al}\left(\mathrm{FB}_{\mathrm{Al}-\mathrm{P}}\right)$ and $\mathrm{Fe}$ $\left(\mathrm{FB}_{\mathrm{Fe}-\mathrm{P}}\right)$. Bar graphs show experimental data.

biochar samples and could be potentially available in the long term if the soil conditions are suitable for the dissolution or exchange of $P$ from host phases (Al-P and Fe-P compounds) in the biochar samples.

\section{Economic and environmental aspects}

Phosphate mineral resource limitation, soil P fixation, and $\mathrm{P}$ contamination from excessive fertilization have called great attention to effective phosphate fertilizer use for agricultural and environmental sustainability. Recycle, reuse, and recovery are necessary for agriculture and industries, including the sugar industry [40]. A utilization of filter cake, an effective by-product in the sugar industry, as an adsorbent for phosphate contaminant recovery and subsequently recycle into agricultural lands as $P$ fertilizer could be an effective technology to solve this issue. Costs related to metal-engineered biochar production are derived from modification processes (metal impregnation and pyrolysis), while several benefits are waste recycling, water contaminant reduction, and decreasing P fertilizer cost. However, in real practice, biochar engineering could be developed to be cheaper and more effective technology. Applications of biochar-based pollutant removers required more investigation to unravel such adverse impacts of toxic pollutants from a water body. Furthermore, possible real operating systems (i.e., natural water body or industrial water treatment system) remain to be improved for future uses. The application of P-laden biochar-based P fertilizer also required further investigation in various soil and plant types in pot experiments or field scales before recommending its application.

\section{CONCLUSION}

The Al- and Fe-engineered biochar samples prepared from filter cake, a main by-product of the sugar industry, showed excellent P sorption capacity from aqueous solution. The $\mathrm{P}$ retention competency of the Fe-biochar was better than that of biochar prepared from orange peel biomass from reported studies. The Al-biochar from the current study had a lower $\mathrm{P}$ retention potential than cottonwood-Albiochar. However, the metal-biochar incorporation into sand material showed that a sufficient fraction of Olsen-extractable P could be regularly released. The extracted P content from the metal biochar was only approximately $1 \%$ of their total P content, indicating that a substantial amount of the $P$ fraction remained in the biochar matrix and could be considered a long-term source and sink of $\mathrm{P}$ for plant use. This study has shed light on the possible use of Al- and Fe-biochar for improving P availability in sandy soils that are typically low in water and nutrient retention capacity. The $\mathrm{P}$ reclamation from wastewater using both $\mathrm{Al}$-and $\mathrm{Fe}$ - biochars and their subsequent incorporation as $\mathrm{P}$ fertilizers in sandy soils under the field condition should be further investigated.

Acknowledgements: The authors thank the Kasetsart University Research and Development Institute (KURDI), Bangkok, Thailand for research funding (Grant No. 18.58).

\section{REFERENCES}

1. Lehmann J, Joseph S (2015) Biochar for Environmental Management, Saxon Graphics Ltd, NY, USA.

2. Sohi S, Lopez-Capel E, Krull E, Bol R (2009) Biochar, climate change and soil: a review to guide future research. CSIRO Land and Water Science Report 05/09, CSIRO, Australia.

3. Mohan D, Abhishek K, Sarswat A, Patel M, Singh P, Pittman CU (2018) Biochar production and applications in soil fertility and carbon sequestration: a sustainable solution to crop-residue burning in India. RSC Adv 8, 508-520.

4. Ahmad M, Rajapaksha AU, Lim JE, Zhang M, Bolan N, Mohan D, Vithanage M, Lee SS, et al (2014) Biochar as a sorbent for contaminant management in soil and water: a review. Chemosphere 99, 19-33.

5. Lee C, Lim W (2006) Variation of harmful algal blooms in Masan-Chinhae Bay. ScienceAsia 32, 51-56. 
6. Zheng YL, Gao B (2019) Reclaiming phosphorus from secondary treated municipal wastewater with engineered biochar. Chem Eng J 362, 460-468.

7. Yao Y, Gao B, Chen JJ, Yang LY (2013) Engineered biochar reclaiming phosphate from aqueous solutions: mechanisms and potential application as a slow-release fertilizer. Environ Sci Technol 47, 8700-8708.

8. Vikrant K, Kim K-H, Ok YS, Tsang DC, Tsang YF, Giri BS, Singh RS (2018) Engineered/designer biochar for the removal of phosphate in water and wastewater. Sci Total Environ 616, 1242-1260.

9. Chaiyaraksa C, Lokham N, Kuikrong R, Artsanapaiboon S (2020) Immobilization of cadmium in soil using magnetic biochar derived from Eichhornia crassipes. ScienceAsia 46, 450-456.

10. Chen QC, Qin JL, Sun P, Cheng ZW, Shen GQ (2018) Cow dung-derived engineered biochar for reclaiming phosphate from aqueous solution and its validation as slow-release fertilizer in soil crop system. $J$ Cleaner Prod 172, 2009-2018.

11. Zhang M, Gao B (2013) Removal of arsenic, methylene blue, and phosphate by biochar/AlOOH nanocomposite. Chem Eng J 226, 286-292.

12. Ajmal Z, Muhmood A, Usman M, Kizito S, Lu J, Dong $\mathrm{R}$, Wu $\mathrm{S}$ (2018) Phosphate removal from aqueous solution using iron oxides: Adsorption, desorption and regeneration characteristics. $J$ Colloid Interface Sci 528, 145-155.

13. Chen BL, Chen ZM, Lv SF (2011) A novel magnetic biochar efficiently sorbs organic pollutants and phosphate. Bioresour Technol 102, 716-723.

14. Abdala DB, da Silva IR, Vergutz L, Sparks DL (2015) Long-term manure application effects on phosphorus speciation, kinetics and distribution in highly weathered agricultural soils. Chemosphere 119, 504-514.

15. Suriyagoda L, De Costa W, Lambers H (2014) Growth and phosphorus nutrition of rice when inorganic fertiliser application is partly replaced by straw under varying moisture availability in sandy and clay soils. Plant Soil 384, 53-68.

16. Borchard N, Wolf A, Laabs V, Aeckersberg R, Scherer H, Moeller A, Amelung W (2012) Physical activation of biochar and its meaning for soil fertility and nutrient leaching: a greenhouse experiment. Soil Use Manage 28, 177-184.

17. Bruun EW, Petersen CT, Hansen E, Holm JK, Hauggaard-Nielsen H (2014) Biochar amendment to coarse sandy subsoil improves root growth and increases water retention. Soil Use Manage 30, 109-118.

18. Lehmann J, Rondon M (2006) Biological Approaches to Sustainable Soil Systems, CRC Press/Taylor \& Francis Group, Florida, USA.

19. USDA (2020) Sugar: World Markets and Trade. Foreign Agricultural Service.

20. Chauhan MK, Chaudhary S, Kumar S (2011) Life cycle assessment of sugar industry: A review. Renew Sust Energ Rev 15, 3445-3453.

21. Prado RdM, Caione G, Campos CNS (2013) Filter cake and vinasse as fertilizers contributing to conservation agriculture. Appl Environ Soil Sci 2013, ID 581984.

22. Poddar PK, Sahu O (2017) Quality and management of wastewater in sugar industry. Appl Water Sci 7, 461-468.

23. Klüpfel L, Piepenbrock A, Kappler A, Sander M (2014) Humic substances as fully regenerable electron acceptors in recurrently anoxic environments. Nat Geosci 7, 195-200.

24. Chen M, Ma LQ (2001) Comparison of three aqua regia digestion methods for twenty Florida soils. Soil Sci Soc Am J 65, 491-499.

25. Murphy J, Riley JP (1962) A modified single solution method for the determination of phosphate in natural waters. Anal Chim Acta 27, 31-36.

26. Sparks DL, Page A, Helmke P, Loeppert R, Soltanpour P, Tabatabai M, Johnston C, Sumner M (1996) Methods of Soil Analysis, Part 3 - Chemical Methods, American Society of Agronomy, Inc., Soil Science Society of America, Inc., USA.

27. Klute A (1986) Water retention: laboratory methods. In: Klute A (ed) Methods of Soil Analysis: Part 1 Physical and Mineralogical Methods, 2nd Edn, American Society of Agronomy, Inc., Soil Science Society of America, Inc., USA, pp 635-662.

28. Van't Hoff JH (1887) Die Rolle des osmotischen Druckes in der Analogie Zwischen Losungen und Gasen. Z Physik Chemie 1, 481-493.

29. Feher JJ, Ford GD (1995) A simple student laboratory on osmotic flow, osmotic pressure, and the reflection coefficient. Adv Physiol Educ 268, 10-20.

30. Yusiharni E, Gilkes RJ (2012) Minerals in the ash of Australian native plants. Geoderma 189, 369-380.

31. Olsen SR (1954) Estimation of Available Phosphorus in Soils by Extraction with Sodium Bicarbonate, US Department of Agriculture, USA.

32. Sposito G (1980) Derivation of the Freundlich equation for ion exchange reactions in soils. Soil Sci Soc Am J 44, 652-654.

33. Kollist $\mathrm{H}$, Jossier $\mathrm{M}$, Laanemets $\mathrm{K}$, Thomine $\mathrm{S}$ (2011) Anion channels in plant cells. FEBS $J$ 278, 4277-4292.

34. Wu, LP, Zhang, SR, Wang, J, Ding XD (2020) Phosphorus retention using iron (II/III) modified biochar in saline-alkaline soils: Adsorption, column and field tests. Environ Pollut 261, ID 114223.

35. Menon R, Chien S, Hammond L (1990) Development and evaluation of the Pi soil test for plantavailable phosphorus. Commun Soil Sci Plant Anal 21, 1131-1150.

36. Mallarino A, Blackmer A (1992) Comparison of methods for determining critical concentrations of soil test phosphorus for corn. Agron J 84, 850-856. 
37. Fang C, Zhang T, Li P, Jiang RF, Wang YC (2014) Application of magnesium modified corn biochar for phosphorus removal and recovery from swine wastewater. Int J Environ Res Public Health 11, 9217-9237.

38. Takaya CA, Fletcher LA, Singh S, Okwuosa UC, Ross AB (2016) Recovery of phosphate with chemically modified biochars. J Environ Chem Eng 4, 1156-1165.

39. Yao Y, Gao B, Chen J, Yang L (2013) Engineered biochar reclaiming phosphate from aqueous solutions: mechanisms and potential application as a slow-release fertilizer. Environ Sci Technol 47, 8700-8708.

40. Soltangheisi A, Withers PJA, Pavinato PS, Cherubin MR, Rossetto R, Do Carmo JB, da Rocha GC, Martinelli LA (2019) Improving phosphorus sustainability of sugarcane production in Brazil. Glob Change Biol Bioenergy 11, 1444-1455. 